\title{
Orientalism and Ottoman Modernisation in the Discourse of Postmodernism
}

\author{
Prof. Roida Rzayeva \\ Azerbaijan National Academy of Sciences
}

\begin{abstract}
If Orientalism is the critique of modernity, it can be rather considered in a postmodern discourse. New phenomena of global politics, changing moods of mind and cultural discourses again make Orientalism a topical subject. The East has always meant contrast for the West. Yet has it always meant the same? One should particularly note herein a philosophic approach to the problem is necessary instead of the usual and conventional political one, which mostly expresses a unilateral traditional characteristic of Orientalism and interprets it accordingly. There is an opinion Orientalism makes up a paradigm to study non-European histories and cultures using approaches coming after structuralism and postmodernism. As modernized, the East meets/clashes the West while there is no such an opposition in postmodernism, but is co-existence, which echoes the opposition characteristics of Orientalism, unlike the traditional one. At the same time, when analyzing orientalists' works, we often see not a unilateral, but a synthesized approach e.g in those by Turkish one, Hamdi. In any case, many panels by orientalist artists represent combinations which follow a well-known postmodernist motto, both that and the other, unlike the modern world's modernist logic, either that or this.
\end{abstract}

Keywords : postmodernism, Orientalism, modernization, discourse, dialogue.

\section{Introduction}

Today's western art studies connect the critical approach of the orientalist painting to the idea of alienating and constructing the East in the European paintings. Turkish art experts do not categorize few Turkish orientalists as the school representatives due to some elements in their pictures, most likely explicable as a result of differences between the Ottoman society and other Eastern ones, and e.g pictures by Hamdi are defined as thoroughly composed essays about the Ottoman society created in the Western way'. It seems rather natural for the orientalists, who remained modern people in terms of their habits and mode of life and invented their personal East; the painters were a part of the cultural environment they depicted, the part logically generated by the local tradition historically developing.

In the 15th-17th centuries, the Ottoman Empire represented a cultural space mixing artistic traditions seemingly impossible to combine, which made the Ottoman culture extremely receptive and open for influences. Ornamental motifs are the examples thereof, which may provide for an impression that Ottoman artists wanted to try all and at once, which also echoes with postmodernism. With its natural beauty and architectural sights, Istanbul served a fairy-tale decor for the 19th century's orientalist painters. Not only does Orientalism include a prejudicial western look at the East, but also how this prejudice gradually changed. Meeting fine beliefs and lifestyles where western artists came, full of fairy-tale expectations, along with cultural transforming the empire brought to some thinking stereotypes destroyed, points of view changed and artistic experiences enriched².

The discourse based on the East - West opposition borrows typological perceiving the Orientalism history ${ }^{3}$. Because such important topics as the dialogue of cultures make up today's agenda, one can't help agreeing the following words by E.Said,

\footnotetext{
1 Displaying the Orient: Architecture of Islam at Nineteenth-Century World's Fairs. Berkeley - Los Angeles - Oxford, 1992. P. 40-41

2 Germaner, Semra (2007), "Oryantalizm ve Osmanlı Modernleşmesi”, Uluslararası Oryantalizm Sempozyumu 9-10 Aralık 2006, 1. bs. İstanbul: İstanbul Büyükşehir Belediyesi Kültürel ve Sosyal İşler Müdürlüğü Yayınları, p. 309.

${ }^{3}$ Keyman, E. Fuat (2007), "Edward Said ve Bir Modernite Eleştirisi Olarak Oryantalizm", Uluslararası Oryantalizm Sempozyumu 9-10 Aralık 2006, 1. bs. İstanbul: İstanbul Büyükşehir Belediyesi Kültürel ve Sosyal İşler Müdürlüğü Yayınları, s. 129;
} 
these two geographical essences support and to a certain extent reflect each other ${ }^{1}$. Using Said's postulate, it is the East the West includes as a part (and vice versa), one could wonder in this prism if those who were painting on European history could be inventing the West in this way. After all, we often face an orientalist project and style (using Said's terminology) in the pictures, which represents a synthesis of the imagined West and East, organic due to mental distinction between the West and East, which we have tried to show through the analysis of art pieces.

If Orientalism is the critique of modernity (Keyman, 2007: 119), then it can be rather considered in postmodern discourse. New phenomena of global politics, changing moods of mind and cultural discourses again make Orientalism a topical subject. Today, when Orientalism again excites researchers, it is necessary to consider and understand the image of the East which has remained in consciousness. (Çınar, 2007: 6-7). The East has always meant contrast for the West. Yet has it always meant the same? (Sunar, 2007: 34). One should particularly note herein a philosophic approach to the problem is necessary instead of the usual and conventional political one, which mostly expresses a unilateral traditional characteristic of Orientalism and interprets it accordingly.

\section{Research Methods}

\subsection{Methodology}

There is an opinion Orientalism makes up a paradigm to study non-European histories and cultures using approaches coming after structuralism and postmodernism. (Hentsch, 1992; O'Hanlon \& Washbrook, 1992). As modernized, the East meets/clashes the West while there is no such an opposition in postmodernism, but is co-existence, which echoes the opposition characteristics of Orientalism, unlike the traditional one. At the same time, when analyzing orientalists' works, we often see not a unilateral, but a synthesized approach e.g. in those by Turkish one, Hamdi. In any case, many panels by orientalist artists represent combinations which follow a well-known postmodernist motto, both that and the other, unlike the modern world's modernist logic, either that or this.

Today's western art studies connect the critical approach of the orientalist painting to the idea of alienating and constructing the East in the European paintings. (Osmanskaya Imperiya, 2007).

According to Turkish scientists, the given position does not apply to Hamdi's works; simultaneously ornaments of orientalist stylistics are visible in his pictures. (Osmanskaya Imperiya, 2007).Turkish art experts do not categorize few Turkish orientalists as the school representatives due to some elements in their pictures, most likely explicable as a result of differences between the Ottoman society and other Eastern ones, and e.g. pictures by Hamdi are defined as "carefully composed essays on Ottoman society, expressed in a Western vocabulary". (Çelik, 1992: 40-41). It seems rather natural for the orientalists, who remained modern people in terms of their habits and mode of life and invented their personal East (Osmanskaya Imperiya, 2007); the painters were a part of the cultural environment they depicted, the part logically generated by the local tradition historically developing.

The European artists-orientalists used the certain form for the description the Near and Middle East. Some Turkish painters including Hamdi, have adopted this form of representation. Thus, the details of "Eastern life" in these works were described precisely enough while the East appeared as sensual, apathetic, stiffened in the Middle Ages. Hamdi is criticized for absence of the image of Ottoman Turkey and for adopting the sight from the outside.

In the 15th-17th centuries, the Ottoman Empire represented a cultural space mixing artistic traditions seemingly impossible to combine, which made the Ottoman culture extremely receptive and open for influences: the Arab East, the Christian West, China, Persia, and India. The Ottoman twiddle represents a simultaneous combination of different components, at the same time was eclectic. Ornamental motifs are the examples thereof, which may provide for an impression that Ottoman artists wanted to try all and at once, which also echoes with postmodernism.

What is the place of these pictures in our orientalist visual culture of the $19^{\text {th }}$ century? If to take into account the exchange which has been carried out between Ottoman Turks and orientalists at this period there is a question how examples of this interaction can throw down a challenge to our understanding of a role of visual culture? (Roberts, 2007: 270).

\footnotetext{
${ }^{1}$ Саид, Э.В. Ориентализм: Западные концепции Востока, Санкт-Петербург 2006, с. 12.
} 
Edward Said provides to us a prism in which we can consider these noted questions. Said's works began to encourage new interpretation orientalist visual culture. He did not write about art. His works, however, offer us model for reflection on how the Western visual culture, according to him, has left its trace in discursive field of Orientalism. From Linda Nochlin's tremendous essay, published in 1983 and being the first transposition of Said's "Orientalism" on history of art, Said's works have taken the form of the important project to analyze and criticize the East in imagination of the West. (Nochlin, 1983: 118-31, 187-91). Recently, art historians ... have reacted to this call by revision of an exchange of cultural forms between local and European artists. (Roberts, 2007: 270-271).

\subsection{Findings}

The western people of art running from negative influence of industrialization in the 19th century and beginning to reconsider Western values, considered the East as a place where they could satisfy the melancholy on natural and pure, interest in exotism, and ennobled it. Ottoman Empire due to rich culture and wide territory in region of Middle East has become focus of attention of the Western critics in different art forms: from literature to painting in this century. (Gemraner, 2007: 299).

During this period many western people of art have a possibility to travel the East, and they face Islamic culture which dominates in this region during these trips and its material products. In memoirs of wandering authors and people of art the countries visited are described with exciting delight; however, customs and traditions seem unusual and are criticized. This point of view is also expressed in art. Traveling artists of the 19th century transfer the illusions, delight, amazement, and criticism on to canvases. (Gemraner, 2007: 299).

In the $19^{\text {th }}$ century Europe it is possible to tell about the collective world of Eastern dreams. People of art and travelers as proof of privileges of visiting Eastern country, often dressing local clothes, ordered the portraits, were photographed, wanted to become a part of the imagined East, getting a new image. (Gemraner, 2007: 300).

With its natural beauty and architectural sights, Istanbul served a fairy-tale decor for the 19th century's orientalist painters. (Germaner, 2007: 304).

Images of Istanbul, capital of Ottoman Empire were one of leading themes of artists-orientalists. These city landscapes of the European artists seeing in painting harmony of Islamic architecture with natural beauty were works of art, at the same time they were of great importance as separate documents. Really, before occurrence of photo and Turkish oil painting we knew Istanbul from these drawings and engravings. Art people representing within the limits of an everyday life monuments of Istanbul, types and ceremonies, in their works survives to this day geographical and social topography which is lost today. There were, however, the artists who have visited Istanbul, but collected pleasant picturesque corners of the city by means of concept "capriccio" in one picture, along with the artists representing panoramas of Istanbul, without having visited a city, copying from photos and engravings and first of all intending to reflect east atmosphere. (Inankur, 2007: 287)

The term "capriccio" meaning in Italian caprice or imagination, from the $18^{\text {th }}$ century is used for the characterizing the architectural imaginations in which real and imagined constructions co-exist under picturesque conditions. "Capriccio" in $\mathrm{XVIII}$ century has turned to one of the most favorite kinds of painting which the notable and rich tourists going to the big travel to Europe to be experienced a little more life and knowledge, after returning to the countries, bought most of all. Artists-orientalists of the 19th century also have borrowed this genre, in pictures sometimes gave a place imagined constructions along with real ones, sometimes transferred to the excellent environment real designs and subjects and connected in any way. The most important reason for such choice of orientalists was to respond to image of the East which has remained in consciousness of the European clients, having shown as far as possible exotic and excellent components together. (İnankur, 2007: 288).

Although components in these pictures which are defined under the name "capriccio" are collected together in an arbitrary way inside not always true from the point of view of history and atmosphere of the main theme (Denny, 1993: 221), reality in each component gives entirely certain «real effect» and persuasiveness to construction. These boards present to Europe the exotic city of Istanbul which Europe wants to see. It is interesting that demand for these pictures of Istanbul that are not absolutely real, but making a real impression, was higher than those where there was truer description of validity. (Inankur, 2007: 298).

If we consider pictures of orientalists as a whole, it appears that some Western people of art create their works examining life of Eastern society through social criteria. These paintings based on biases, prospective phenomena, and on imagined 
show how the western people of art in their way characterize the East and make conclusions about the Eastern society. These people of art try to describe scenes to which they are accustomed in Christian European society, hence, that seemed to them excellent and amazing. This is an interesting and attractive aspect of works. In the pictures the worlds of men and women are divided, even the men represented in the work environment, shown in slower vital rhythm, rather than in the West. (Germaner, 2007: 301).

There are scenes of bath, harem, slave bazaar where the women play a leading role, some images of punishment and battles, violent scenes in pictures. All these pictures are examples exaggerated and based on demand of the consumer. These works deserve real "orientalist" characteristic. It will be possible to comment upon these works from the ideological point of view. (Germaner, 2007: 302).

Orientalist works include not only ideological distortions. Often, they may also contain true information. Some people of art which have visited Eastern countries, living in this geography for a while and knowing these countries, have drawn landscapes, described scenes from life in this territory. In these examples the basic two features are emphasized. First is natural beauty of a place where the picture has been drawn, a climate, exotic plants, and ethnic wealth. The second is a structure of a city or acquaintance with antique and Islamic works. (Germaner, 2007: 302).

These works are the examples bearing the information, and they have played an important role in representation of the Islamic world and art to the West. Hence, if we can tell about a part of orientalists' pictures that they tried to reflect a radical difference between Eastern cultures, lifestyle and the West, "uncivilized" in accordance with Western standards, but at the same time mysterious (mystical) in them, then examples of different types of landscape thus are not estimated. (Germaner, 2007: 302).

Interest in the East was in fashion in the 18th century, and began to grow to a greater extent, pursuing political ends in the $19^{\text {th }}$ century. (Germaner, 2007: 303).

The works connected with Ottoman painting and patronage to art, revision of interaction between Ottoman Turks and orientalists in Istanbul in 19th century, have played the central role in revaluation of this area. (Germaner \& Inankur, 2002; Çelik, 2002: 19-41). These two directions in discussions about art history have made Said's Orientalism opening new horizons their pivot. However, neither Said's book marked a turning-point, nor its literary works, have not introduced the alternative approach to questions concerning intercultural exchanges, as that he has written about music. (Roberts, 2007: 271).

Choice of the exotic or "mystical" East as the main theme of the works by the western people of art for the ideological reasons or as a source of good profit during this period when Ottoman Empire on reforms addresses to the West, is interesting coincidence. The face of Empire beginning to Westernize has provoked considerable disappointment in people of art and travelers. Ms. Pardoe criticizing changes in clothes of Mahmud II expresses her disappointment at the sight of almost everywhere the ugly and senseless tarboosh which have almost completely replaced dazzling muslin and cashmere turban, and condemns adopting a bad semblance of the European clothes deprived of elegance. (Pardoe, 1999: 4).

In these years, however, expectations in Ottoman Empire opened to the Western influence in the politic and economy as well in art are different. While some European people of art came to this country at their own expense to create orientalist works, others has been invited and authorized by the palace. The Ottoman sultan and Tanzimat pashas, as well as European heads and statesmen wanted to perpetuate their image, give orders to these artists. (Germaner, 2007: 304-305).

Such people of art as Pierre Désiré Guillemet, Stanislaw Chlebowski, Louis Acquarone, and Fausto Zonaro have conferred a title of "the palace artist". Such artists as Alberto Pasini, Ivan Konstantinovich Aivazovsky, Rudolf Ernest also received orders from the palace and Ottoman bureaucrats. These people of art, besides orders, have become famous as artistsorientalists for their pictures from life of Ottoman Empire, exhibited in halls of Paris and London. (Germaner, 2007: 305).

A considerable part of orders of a palace to the Western artists coming to Istanbul is the scenes of ceremonies showing innovations in army and clothes. After the reforms which have been carried out by Mahmud II in clothes, it began to be observed that these ceremonies became much simpler in comparison with the past. It is frequently observed that the sultan and other officials are dressed in tarbooshes and uniforms, however women and men, come to observe a train or parade are dressed in traditional clothing. These pictures showing Ottoman sultan, urban population in authentic clothes, Eastern architecture with a mosque and springs, on the one hand, have orientalist features, on the other hand, are the first illustrative 
documents of the society which are in process of transformations. Besides, these examples provide information on changes in the clothes, being the first displays of Westernization movement, and wearing clothes of new style by statesmen and military men. (Germaner, 2007: 306).

Theme of pictures also is Ottoman army reorganized according to the Western models and a modern education system. (Germaner, 2007: 307).

This tangle of relationships and collisions in the $19^{\text {th }}$ century can be characterized as examples of mutual relations between cultures of the East and the West and as one of the ways leading to Western modernism. (Germaner, 2007: 309).

\section{Results and Discussion}

Said's "Orientalism" in which he establishes a look of the West at the East, has expanded sphere of influence of social thought. (Çınar, 2007: 6).

On the other hand, his concepts and form of analysis offers new possibilities for different solution of relations between civilizations which we often face in present period. There is a wide variety of Orientalism indicators, which is not limited to only intellectual sphere. This variety includes such areas, as architecture, art, literature, music, and theology. (Çınar, 2007: $6)$.

Not only does Orientalism include a prejudicial western look at the East, but also how this prejudice gradually changed. Meeting fine beliefs and lifestyles where western artists came, full of fairy-tale expectations, along with cultural transforming the empire brought to some thinking stereotypes destroyed, points of view changed and artistic experiences enriched. (Germaner, 2007: 308-309.)

The discourse based on the East - West opposition borrows typological perceiving the Orientalism history (Keyman, 2007: 129). Because such important topics as the dialogue of cultures make up today's agenda, one can't help agreeing the following words by E.Said, these two geographical essences support and to a certain extent reflect each other. (Said, 2006: 12). Using Said's postulate, it is the East the West includes as a part (and vice versa), one could wonder in this prism if those who were painting on European history could be inventing the West in this way. After all, we often face an orientalist project and style (using Said's terminology) in the pictures, which represents a synthesis of the imagined West and East, organic due to mental distinction between the West and East, which we have tried to show through the analysis of art pieces.

\section{References}

[1] Çelik, Z. (1992). Displaying the Orient: Architecture of Islam at Nineteenth-Century World's Fairs. Berkeley: University of California Press. - Los Angeles - Oxford, 1992.

[2] Çelik, Z. (2002). Speaking back to orientalist discourse. In (Ed.), J.Beaulieu, \& M. Roberts Orientalism's interlocutors. Painting architecture, photography (pp. 19-41). Durham: Duke University Press.

[3] Çınar, Ahmet (2007). Oryantalizm Sempozyumunun Ardından, Uluslararası Oryantalizm Sempozyumu 9-10 Aralık 2006 (pp.5-7), 1. bs. İstanbul: İstanbul Büyükşehir Belediyesi Kültürel ve Sosyal İşler Müdürlüğü Yayınları.

[4] Denny, W.B. (1993). Quotations in and out of Context: Ottoman Turkish art and European orientalist painting. In (Ed.), M.B. Sevcenko Muqarnas X: An annual on Islamic Art and Architecture (pp. 219-230). Leiden: E. J. Brill.

[5] Germaner, S. \& Inankur, Z. (2002). Constantinople and the orientalists. Istanbul: İşbank.

[6] Germaner, Semra (2007). Oryantalizm ve Osmanlı Modernleşmesi. Uluslararası Oryantalizm Sempozyumu 910 Aralık 2006 (pp.299-309) 1. bs. İstanbul: İstanbul Büyükşehir Belediyesi Kültürel ve Sosyal İşler Müdürlüğü Yayınları.

[7] Hentsch, T. (1992). Imagining the middle east. New York: Black Rose Books;

[8] İnankur, Zeynep (2007). İstanbul Kaprisleri. Uluslararası Oryantalizm Sempozyumu 9-10 Aralık 2006 (pp. 287298). 1. bs. İstanbul: İstanbul Büyükşehir Belediyesi Kültürel ve Sosyal İşler Müdürlüğü Yayınları.

[9] Keyman, E. Fuat (2007). Edward Said ve Bir Modernite Eleştirisi Olarak Oryantalizm. Uluslararası Oryantalizm Sempozyumu 9-10 Aralık 2006 (pp. 119-130). 1. bs. İstanbul: İstanbul Büyükşehir Belediyesi Kültürel ve Sosyal İşler Müdürlüğü Yayınları. 
[10] Nochlin, L. (1983, May). The imaginary orient. Art in America, 71 (5), 118-31, 187-91.

[11] O'Hanlon, R., \& Washbrook, D. (1992). After orientalism: Culture, criticism and politics in third world. Comparative Study of Society and History, 34, 141-167.

[12] Pardoe, J. (1999). Miss Pardoe'nun gözüyle 19. yüzyıl Osmanlı yaşantısı. İstanbul: Boyner Yayınları.

[13] Roberts, Mary (2007). Karşıtlıklar: Said, Sanat Tarihi ve 19. Yüzyıl İstanbul'undaOsmanlı Kimliğini Yeniden Keşfetmek. Uluslararası Oryantalizm Sempozyumu 9-10 Aralık 2006 (pp. 269-285). 1. bs. İstanbul: İstanbul Büyükşehir Belediyesi Kültürel ve Sosyal İşler Müdürlüğü Yayınları.

[14] Саид, Э.В. (2006). Ориентализм: Западные концепции Востока, Санкт-Петербург.

[15] Sunar, Lütfi (2007). Şarkiyatçılığı Niçin Yeniden Tartışmalıyız?, Uluslararası Oryantalizm Sempozyumu 9-10 Aralık 2006 (pp. 27-53). 1. bs. İstanbul: İstanbul Büyükşehir Belediyesi Kültürel ve Sosyal İşler Müdürlüğü Yayınları.

[16] Османская империя Турецкий ориентализм. [Online] Available: http://community.livejournal.com/osmanenerbe/23124.html (December 21, 2007) 